\title{
Human Capital Accounting: Global Theoretical Model
}

\author{
San Lio \\ United States International University-Africa
}

Received: Sep. 16, $2021 \quad$ Accepted: Dec. 22, $2021 \quad$ Published: Dec. 1, 2021

doi:10.5296/ajfa.v13i2.18927 URL: https://doi.org/10.5296/ajfa.v13i2.18927

\begin{abstract}
Human Capital (HC) is the sole intervening factor for a competitive hedge in all firms: merchandising, manufacturing, or servicing. However, the need for $\mathrm{HC}$ is enhanced in service firms because only they can act. All requisite tangible and intangible assets of firms are accounted for as material investments in their financial reports for improved decisions by managers and other stakeholders. However, contemporary organizations are unable to account for their HC investments because there is no Generally Accepted Legal Framework (GALF). This is even though HC accounting discipline has attracted attention in most jurisdictions, although it was largely disregarded in some parts of the world and the deliberations date back to the early sixties of the last century. Could the exploration of HC accounting underpinning theories offer practitioners research insights?
\end{abstract}

Keywords: Human Capital Accounting, Human Capital Accounting Theories, Human Resource Accounting Structure, Models in Human Resource Accounting 


\section{Macrothink}

Asian Journal of Finance \& Accounting ISSN 1946-052X 2021, Vol. 13, No. 2

\section{Introduction}

No firm can function without Human Capital. Historical manufacturing firms; the ever-evolving merchandising firms, as well as modern KISS firms (Lio, 2018) require HC as requisite material investments.

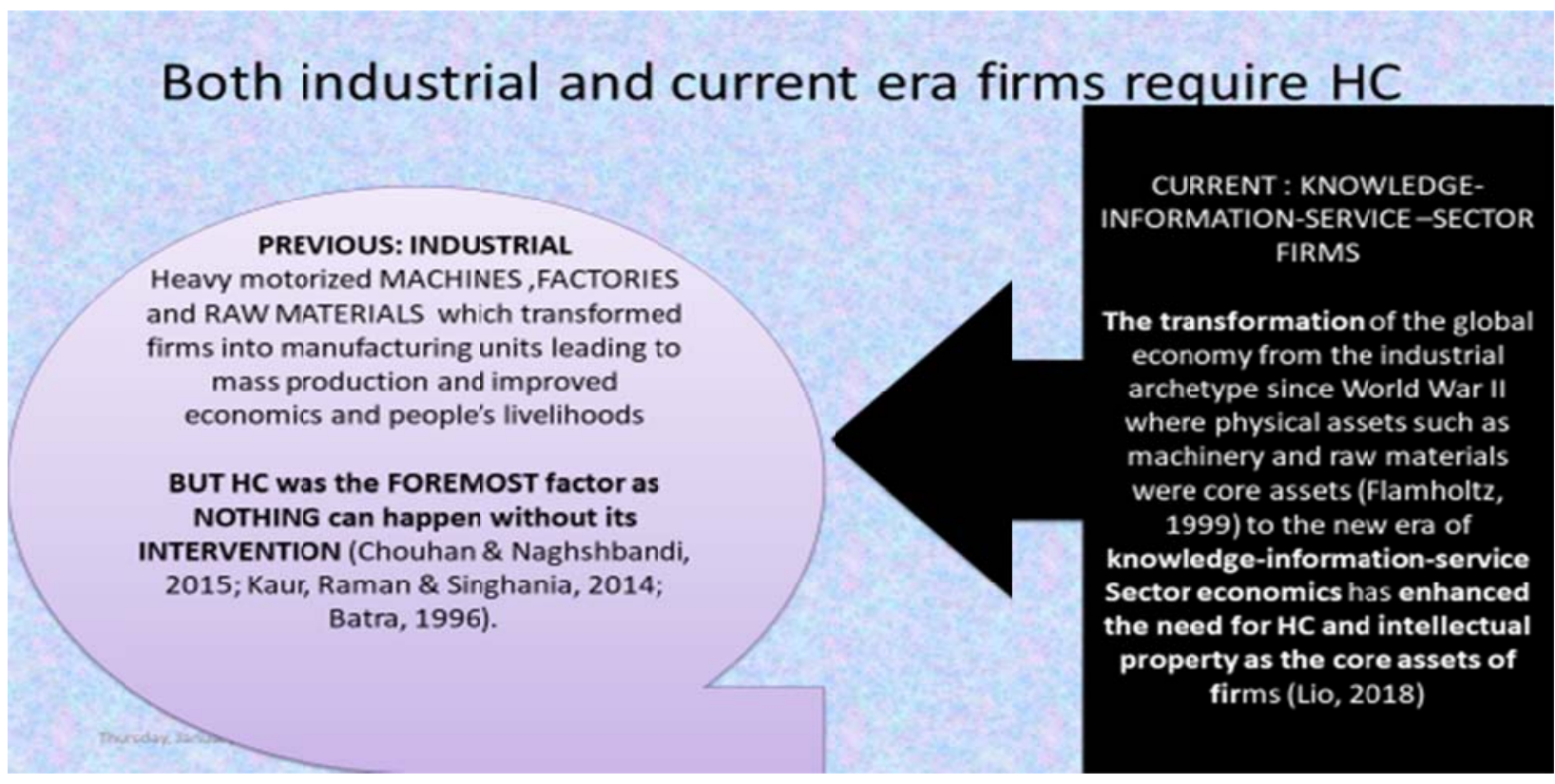

Figure 1.1

The Human brain and hand must conceive any known innovation and technology.

\section{HRA Global Theoretical Model}

The global model in Human Resource Accounting (HRA) is presented in Figure 1.1 


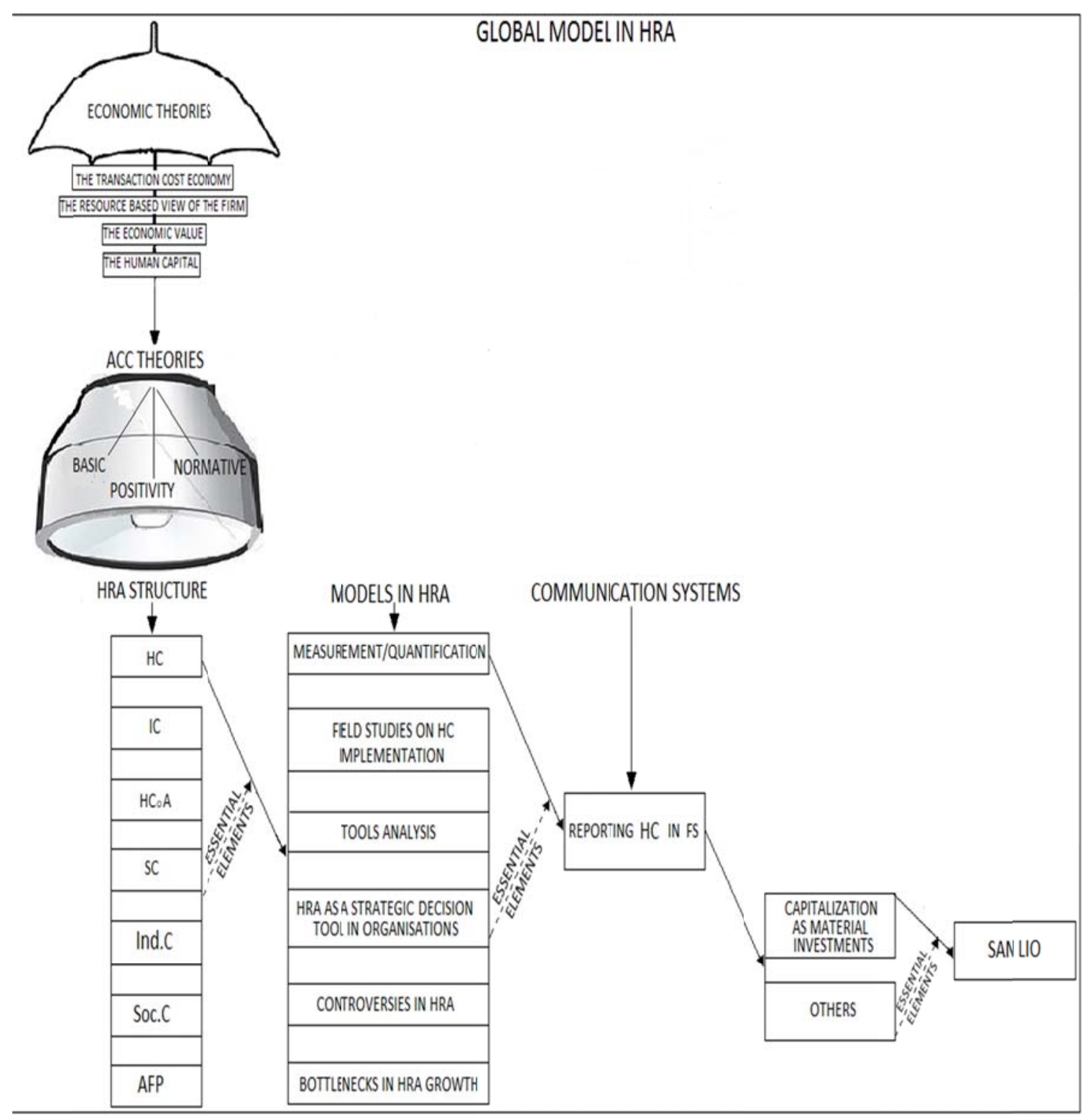

Figure 2.1 Global Model in Human Recourse Accounting: Source: Researcher, 2021

Empirical research underpins theoretical frameworks to enable readers can comprehend how questions and aims were reconnoitered (Tong, Sainsbury, \& Craig, 2007). Accounting is founded on economics, as it is a measurement-communication system of economic value propositions. Economic theories such as the Transaction Cost Economic Theory (TCET), the Resource-Based View of the Firm Theory (RBVFT); the Human Capital Theory (HCT), as well as the Economic Value Theory (EVT) originate their key accounting (ACC) counterparts of Basic, Normative, and PAT theories used in this analysis to promote Human Capital Accounting (HCA) practice in Figure 2.1.

The global model in Figure 2.1 depicts a 'parasol' and a 'torch'. The parasol represented the four economic theories used in this enunciation; and the torch their ensuing ACC counterparts. The parasol view was fundamental in 'shielding' (invigorating) the highly professionalized 
accounting vocation from 'negative weather'(risks) so that it should function in organizations and 'torch' the substantive propositions that relate it to measurement-communication decision models and decision making in organizations. As depicted in the model, economics did not merely promote the ACC existence, but its coherent truths make it function pragmatically. Accordingly, the torch would give life to Human Resource Accounting (HRA), as a HC accounting discipline. The torch analogy implied that the HRA, as a strategic decision model, should logically function, and be embraced or adopted by key constituents in organizations. American Accounting Association (AAA) (1973) has proposed that for ACC to be a measurement-communication system, the theory of accounting should be considered as a set of substantive propositions that link accounting measurements to decision models (the semantic part) and decision making (the pragmatic part) in organizations. These underlying truths were essential in aiding practitioners as well as researchers to pose the right questions to promote their study objectives in HRA.

\subsubsection{The Parasol}

Economics theories of TCET, the RBVFT, HCT, and the EVT were used as key informants of the ACC theories used in this review and designated as the parasol.

\subsubsection{The Transaction Cost Economy Theory}

Transaction Cost Economy Theory is founded on the premise that hiring and training costs matter to organizations when making decisions relating to $\mathrm{HC}$ deployment. Therefore, they choose between recruiting new employees from outside the firm in which case hiring or Acquisition Costs (AC) will occur, or train (reposition) existing ones in which case training or Learning Costs (LC) become inevitable. Inasmuch, they elect to employ HC in the most efficient manner (Chaudhry \& Roomi, 2010; Argyres \& Liebeskind, 1999). TCET has become the dominant focus in contracting of HC (Schepker, Oh, Martynov \& Poppo, 2014) as it has a hub on the governance implications of asset specificity, as a form of asset-based co-specialization within entities (Joskow, 1993; Riordan \& Williamson, 1985). Riordan and Williamson (1985) propose that between the outside hiring (AC) and internal training (repositioning) LC alternatives, firms chose the most efficient combination. Asset specificity in terms of the ACC of the actual cost of HC in the HRA branch of accounting and governance and/or control were key tenets to be explored. More specifically, the AC and LC are essential metrics in accounting for $\mathrm{HC}$ in organizations. Accordingly, this theory would be applied to promote the ACC relationships between HC costs and Human Capital Earning Potential (HCEP) in organizations. This remains the goal of HRA practice.

\subsubsection{The Resource-Based View of the Firm Theory}

The RBVFT is a core skill-focused view, which presupposes that those rare competencies and skills essential for a firm's competitive edge should be nurtured and repositioned from within the firm itself, and then supportive systems such as outsourced technology are introduced. According to this theory, resources and capabilities are heterogeneously distributed among firms, and that they are imperfectly mobile (Karthikeyan, Bhagat, \& Kannan, 2012). Barney (1991) found that the rare competencies were HC qualities such as value, rareness, not being 
imitable, and immobility. Ray, Barney, and Muhanna (2004) propose that resources were a source of competitive advantage only if they were used to do something, or were exploited through business processes and that those business processes and activities that used these valuable, rare, inimitable, and non-substitutable resources were sources of competitive advantage to the firm. Porter (1985) opines that HC with rare skills was the roots of a firm's competence and profits. $\mathrm{HC}$ which possessed these attributes would be the ultimate attention of any firm (Porter \& Stern, 2001). Chen and Lin (2004) stipulate that the way a firm formed, obtained, maintained, and segregated these categories of $\mathrm{HC}$ would equal its quantified disclosure of HC investments. Lepak and Snell (1999) distinguished between high uniqueness and high value of $\mathrm{HC}$, as well as low uniqueness and low-value $\mathrm{HC}$ in a quadrant. They concluded that $\mathrm{HC}$ possessing high uniqueness and high value were nurtured from within the company and that the company continued to invest in these assets as possessing the rare skills that drove its competitive advantage. $\mathrm{HC}$ costs in this regard included: learning costs at the middle stages of development and replacement costs at the final stages of development. Firm managers would account for the quantitative value of their HC in HRA to effectively manage the firm's competitive edge by especially focusing on learning and growth proposed in Kaplan and Norton (1992). Accounting for HC in organizations would be useful in facilitating firms to reposition their key $\mathrm{HC}$ in the most profitable strategic functions. Accordingly, this theory would be fundamental in promoting the adoption of the HRA discipline in organizations.

\subsubsection{The Human Capital Theory}

Third, is the HCT, which is founded on the premise that firms acquire sufficient HC based on its potential future economic benefits to be derived from it. $\mathrm{HC}$ in this theory possesses the dual qualities of specialized core competencies and non-transferability (Chen \& Lin, 2004). The theory described $\mathrm{HC}$ in terms of investments made in training and knowledge building among employees (Chaudhry \& Roomi, 2010). Investments in HC were acquired through training and retention (Flamholtz, 1999). Becker (1993) promoted that HC could grow either general skills that could easily be transferred to organizations or firm-specific skills unique to the firm and which were harder to apply in another firm. He originated that if employees with firm-specific skills were compensated for at least a portion of the increased economic benefits linked with such skills, interim employee mobility would accrue a monetary penalty. Accordingly, HC with firm-specific skills would opt to stay, and hence retention achieved. It is imperative that KISS firms employed robust pay schemes aimed at retaining their HC competencies that drove their profitability. Thus, this theory would affirm the notion that: to be adopted in organizations; the HRA as a strategic decisions tool would promote the ACC of Total Human Capital Cost (THCC) in organizations, to be matched with HCEP as well as the Actual Human Capital Revenue (AHCR) to be derived from it. The theory would therefore be applied to typify the basis upon which organizations can accurately forecast their HCEP in tandem with the matching postulate.

\subsubsection{The Economic Value Theory}

The EVT presumes that all employees in firms bear value since they are capable of rendering 
future services to organizations. Foster (2001) has argued that evidence rationally led to the inescapable conclusion that firms' only choice was to accept economic efficiency in the instrumental sense as their criterion of judgment, as their theory of value. The individual value of $\mathrm{HC}$ has been defined as the present value of the future services expected to be derived from each employee for the period they were expected to remain in the firm (Flamholtz, 1999). Thus in the EVT, the efficiency of HC in the quest for economic value addition within the firm for the entire period of work was the overriding factor. According to Butt (2013), HRA took cognizance of the efforts employed by all those that work in a particular organization and at whatever level of engagement, including directors, managers, or other functional structures. Human Capital Accounting presupposes that $\mathrm{HC}$ is the intervening factor for competitive advantage in organizations. This theory would promote the view that $\mathrm{HC}$ is the foremost investment in organizations, and especially KISS firms of the current dispensation. Investments in HC would be accounted for in HRA to promote managerial decisions which augment firm market value.

\subsubsection{The Torch}

The four key economic theoretical foundations were the basis upon which the fundamental ACC theories of basic, normative, and positivity view; designated as the torch in the enunciation originate. The ACC theories promote the HRA discipline. The economics and finance disciplines provide useful analytical concepts for measuring HC programs and their impacts on organizations (Cascio \& Boudreau, 2011). Ijiri (1975) suggested that the key issue in ACC was the measurement of the economic performance of the accounted.

\subsubsection{The Basic Accounting Theory}

Basic ACC theory has been identified as a cohesive set of conceptual, hypothetical, and pragmatic propositions explaining and guiding the accountant's actions in identifying, measuring, and communicating economic information to users of financial reports (AAA, 1973; AICPA, 1970). It was highlighted in the statement of Basic Accounting Theory (ASOBAT) as the process of identifying, measuring, and communicating economic information to permit informed judgments and decisions by users of the information (Sadan \& Auerbach, 1974). AAA (1973) further identified basic ACC theory as the measurement activity for certain kinds of decision models. According to Kabir (2005), the underlying issue in ACC was the measurement of the economic performance of the accounted. Perara and Matthew (1996) proposed that basic ACC theory was the logical reasoning in the form of broad principles that provide a general frame of reference to every accountant to evaluate and guide the development of new practices and procedures. Wolk, Dodd, and Rozycki (2008) found that the theory consists of basic assumptions, definitions, principles, and concepts and how they were derived, and it included the reporting of ACC and financial information. These definitions uphold what Romeo and McKinney (2008) proposed to be the key activities of accountants, namely, to read the record, the hieroglyphics of accounts, whether unmistakably or blindly prepared, and to interpret, rearrange, and produce in a simple but distinct form, self-explanatory and free from mysteries of bookkeeping, the narrative of facts as they were, their relation to each other and intrinsic results. Accordingly, basic ACC theory was 
acknowledged in this inquiry as a measurement and quantification tool of firms' valuable economic results in their financial reports to enable managers and other key constituents to make informed decisions. HRA, as a unique branch of ACC, aspires to account for the quantitative value of $\mathrm{HC}$ as the most fundamental investment in organizations for better decisions. The theory would therefore be applied as the basis of the HRA discipline in guiding the contemporary accountant's work of identifying, measuring, and communicating THCC and AHCR in their organizations.

\subsubsection{The Normative Accounting Theory}

The normative ACC theory seeks to prescribe some basis of ACC measurement, particular ACC procedures, and the contents of financial reports (Watts \& Zimmerman, 1986). The normative ACC theory notion presupposes measurement and recognition issues in ACC (Kabir, 2005), and measurement was about determining the quantitative value of assets in firms for improved decisions. Ijiri (1975) viewed the normative theory as deductive, which started with some goal assumptions and then deduced ACC procedures. However, Littleton (1953) considered normative theory as inductive and argued that it examined extant accounting practice and then rationalized and justified the major elements of the existing accounting practice. Ijiri (1975) distinguished between inductiveness and deductiveness and argued that the goal assumptions in normative models or goals advocated in policy discussions were often stated based on one's convictions and preferences rather than based on an inductive study of the existing system. Kabir (2005) contended that it was infeasible to classify work as being inductive or deductive only, as some works utilized both models. This was a reasonable proposal as the existing practice promoted in Ijiri (1975) had its origins in some assumptions and goal propositions that deduced its existence. Furthermore, ACC presumed the objectivity postulate when assumptions were employed, as this analysis hinged on the deductive approach. Nonetheless, the normative ACC theory is a measurement system of economic values, and paths on clear procedures and processes as envisaged in HRA, and it hugely supplements both the basic and positive theoretical frameworks.

However, the normative theory was criticized as being prescriptive (Miller \& Bahnson, 2010; Sinha, 2008). Although with emphasis on recognition and measurement issues in ACC, there was a lack of agreement among the theorists on the basic assumptions and hypothesized information needs of users, and these differences led to different recognition and measurement proposals (Kabir 2005). Ramirez and Jeanjean (2009) suggested that normative theory progressively defined itself as a set of knowledge which, while remaining in touch with the possible uses of that knowledge, was nevertheless detached from those uses to exist as a system of knowledge; and this created a distance between the theorists and the professional ACC world. Nevertheless, they added that the success of the normative theorists appears to have paved the way for the success of the positivity theory; and concluded that indeed, normative research was not killed off by the rise of positive research. This investigation employed the normative perspective as the basis upon which advanced ACC theoretical frameworks are derived to promote the HRA discipline. The theory would be applied to underpin the foundation of HCA in organizations for improved decisions which enhance firm value. 


\subsubsection{The Positivity Accounting Theory}

The PAT is a measurement-quantification-procedural approach that seeks to communicate and explain the interconnectedness between the ACC practice and the social-political-economic paradigms in organizations. According to Sinha (2008), the primary objective of the PAT was to explain and predict ACC practices. PAT is a scientific, empirical, economic-based theory and explanatory of the ACC practice (Chambers, 1993). Watts and Zimmermann (1986) stipulated that the positivity view was based on the intention to explain and predict ACC practice rather than improve them, and was a scientific theory since it was consistent with the view of theory in science. In their first article on positivism, Watts and Zimmerman (1986) explicitly championed a methodology that would focus empirical research in accounting theory on economic-based explanations and predictions of ACC practice (Boland \& Gordon, 1992). Thus PAT accomplished more than mere economic measurement and quantification to inculcate: first, the impact of ACC information on financial markets (Kothari, 2001); second, the behavioral approach which analyses the relationships between accounting information and human behavior (Bloomfield, Libby, \& Nelson, 2002); and, third, the politico-contractual perspective, which examines the organizational, economic, and political determinants of ACC policy choices made by preparers of accounts (Fields, Lys, \& Vincent, 2001). The positivity framework, although criticized as not being scientific because traditional ACC research was normative (Sinha, 2008), rationale was beyond the essential measurement and recognition parameters in ACC promoted by the basic and normative frames and dealt with the rapidly changing modern economic behavioral relationships in a complex business environment, and how they are accounted. Accordingly, the three theories were complementary in this enunciation. Imke (2001) has suggested that good ACC practice can be the product of good ACC theories. Theeke (2005) proposes that a theory must epitomize its workability and how it fits with other known and accepted theories.

The interconnectedness of the three ACC theoretical frameworks and their economic counterparts has emanated the HRA as a unique branch of ACC whose solitary theme is to measure the quantitative value of $\mathrm{HC}$ as the foremost factor of competitive advantage in organizations. Steen, Welch, and McCormack (2011) have suggested that the focus on measurement and quantification of $\mathrm{HC}$ was understandable with the roots of ACC in source disciplines such as economics and scientific management. HRA was exposed as an accounting discipline in the early 1960s of the last century (Chouhan \& Naghshbandi, 2015; Akintoye, 2012; Theeke, 2005; Hermanson, 1986), when accountants embraced it as a HC strategic decision tool in organizations. This followed an earlier revelation by their economists' counterparts. In this inquiry, the interconnectedness of the theories underpinned the HCA practice.

\subsubsection{The HRA Structure}

In Figure 2.1, the HRA has emanated seven disciplines identified in this depiction as the HRA structure and which include: Human Capital (HC), Accounting For People (AFP), Intellectual Capital (IC), Human Competence Accounting (HCoA), Structural Capital (SC), Individual Capital (Ind.C), as well as Social Capital (Soc.C). These were typified as synonymous with 
HRA practice (Theeke, 2005); and this veracity may have hindered the implementation of the HRA theory in organizations for improved firm market value. It is imperative that an ACC discipline ought to be pragmatically defined for ease of implementation.

\subsubsection{Human Capital}

Most HRA research work has focused on HCA (Roslender, 2009), and has centered on six key thematic areas to include: (i) the analysis of tools of HCA in organizations; (ii) empirical case studies on HRA implementation in organizations; (iii) HRA as a HC strategic decision tool in organizations concerning other tools such as the Balanced Score Card (BSC); (iv) research on controversies in HRA; (v) bottlenecks and impediments to HRA growth; and, (vi) measurement and/or quantification of $\mathrm{HC}$ in the financial statements of organizations (Flamholtz, Narasimhan, \& Bullen, 2004). These were described as Models in HRA in this expose. Various empirical works were carried out especially in companies such as R G Barry Corporation, Touche Ross \& Co., the Metro Bank, the USA Navy, Dow Chemicals, 18 British Football clubs, WM data, Skandia Group and Bharat Heavy Electrical -India, and recently in Kenyan medium and large organizations, among others. Most of these companies implemented ACC for $\mathrm{HC}$ with positive bottom-line results. However, most companies abandoned the practice altogether. Moreover, Flamholtz, et al. (2004) referred to nine empirical works which focused on HRA as aiding managers in organizations to make strategic HC decisions such as selection, tenure, performance, utility analysis, downsizing, competence development, and Human Capital Return On Investment. They further referred to three empirical works on HRA controversies to include that by Roslender (2009) on quantitative versus soft qualitative measurement of HC, and Johanson and Mabon (1998) in support of quantitative measurement of HC in organizations as they impact decisions of both managers and shareholders of organizations, especially those related to firm value and competitiveness.

This expose has distinguished between financial and non-financial measures of HC, and focused on $\mathrm{HC}$ financial measures in the financial reports of entities for improved firm market value: as depicted below: 
Expose is focused on HCA: Much 'smaller' than Human Resource

(HR) which posses deeper immeasurable Social Dynamics (SD) and People (P) which are the Epitome of life (E)

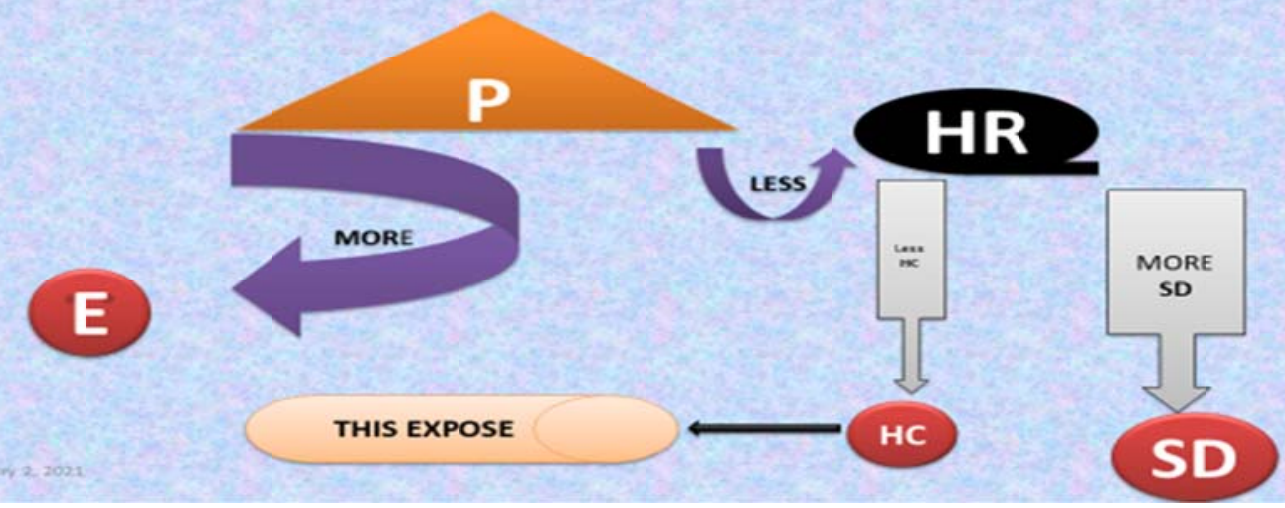

Figure 2.2

Accordingly, impediments to HRA practice, such as lack of concrete tools (Jensen, 2001), skepticism on whether costs outperform benefits (Kaur, et al. 2014), and lack of conceptual frameworks (Theeke, 2005) among others were the underlying phenomenon in this enunciation. A key question was whether requisite theories that originate the HRA discipline were pragmatically employed in empirical investigations to promote the HRA practice.

\subsubsection{Intellectual Capital}

According to Roslender (2009), the concept of IC was originated in the 1990s, and was distinguished and seen as superseding physical capital as the traditional basis for wealth creation. Furthermore, it was seen as financial capital whose importance has remained valid in contemporary business. However, IC was becoming increasingly important and is today the predominant factor in the knowledge-based economy (Gamerschlag, 2013; Murthy \& Guthrie, 2012). Intellectual Capital has been described to include HC, relational, or customer capital, and organizational or structural capital (Abhayawans \& Guthrie, 2016). Relational capital is focused on HC relationships with a firm's external stakeholders. Accordingly, it has been described as Soc.C in this enunciation. Thus IC is broader than its $\mathrm{HC}$ component used in this analysis and includes SC, also discussed here below. Massingham, et al. (2011) argued that HC was the firm's utmost investment because it was the source of creativity, innovation, change, and improvement: as the combined intelligence, skills, and expertise it gave an entity was its unique character. They added that the quest for $\mathrm{ACC}$ for $\mathrm{HC}$ adoption was multidisciplinary, as has been a discussion in economics, strategy, ACC, finance, information systems, legal, and intellectual property. Could interest in IC, as the source of intellectual property, which is accounted for in organizations separately from $\mathrm{HC}$ distinguish IC from HC? For example, machines are the innovation of $\mathrm{HC}$ and are accounted for separately. Unless and until these concerns were fully investigated in empirical works, IC and/or HC accounting would not move past the theoretical phase. 


\subsubsection{Human Competence Accounting}

Murthy and Guthrie (2012) introduced the concept of HCoA when they studied managers in Australian financial firms. However, the authors referred to the originators of HRA discipline while promoting that: terms such as Human Asset ACC, Human Resource ACC, as well as Human Resource costing and ACC, were applied interchangeably to mean ACC for HC. However, HC, as exemplified in this inquiry, has wider tenets than HCoA. Accordingly, based on its original intent, HCoA may better be applied to study divergent competencies on segment employee groups. For example: are older employees more competent than their younger counterparts? Does gender play a role in competence appraisal? Do some countries produce superior products or provide superior services because they house unique competencies? Do some institutions of higher learning inculcate advanced competencies on HC than others? Based on the theoretical intent of HCA, these distinctions are fundamental in promoting the adoption of the practice in organizations for better decisions that augment firm market value.

\subsubsection{Structural Capital}

According to Sveiby (1997:73), SC was originated by 'the Konrad track' group which consisted of managers from Sweden who used nonfinancial indicators to monitor and publicly present their intangible assets. They described SC to encompass: (i) the internal structure which comprised patents, concepts, models, computers, culture, and administrative systems; and (ii) the external structure which nurtured external relationships. SC was described as a component of IC. However, it incorporated administrative systems in organizations as strategic organs which drove the functioning of all assets including financial, physical, operational, markets, and HC. SC, therefore, affirmed the significance of HC, used in this investigation as the intervening factor for competitive advantage in organizations. Notwithstanding the foregoing, SC has been exemplified as a nonfinancial tool, and this scrutiny focused on financial ACC for HC adoption in organizations for better decisions that enhance firm market value.

\subsubsection{Individual Capital}

Flamholtz $(2005: 78,79)$, acknowledged that most HRA works had focused on defining ACC for individual capital (Ind.C) and therefore neglected what he described as 'the human organization as a whole or 'human capital of the third kind' or 'the incremental value of the synergy of the human organization as a whole: as distinct from the value of its members. Flamholtz (1999), promoted Ind.C as the present value of future services to be derived from an employee. However, organizations focus on ACC for their total HC investments, and this was the impetus on this enunciation.

\subsubsection{Social Capital}

Social Capital was synonymous with relational capital in this exploration. Soc.C was defined by Dominguez (2011) as the practice of social behavior by employees, with an effect on a firm's reputation, and cited a 2003 survey by Pricewaterhouse Coopers (PWC) in Spanish companies which found that: a major reason for social disclosure was that it 
enhanced company image. Hooghiemstra (2000) found that Soc.C disclosure led to improved firm reputation and its stock price. However, this review has distinguished between HR in Figure 2.2, with unique non-financial social dynamics, as well as $\mathrm{HC}$, and focused on financial ACC for HC adoption in organizations for superior decisions which augment firm market value.

\subsubsection{Accounting for People}

Accounting for People was expounded by Roslender (2009:143) in response to the fundamental question: 'just why you would want to account for people?' The purpose was to specifically link AFP with the much recent progress associated with intellectual capital, and it drew from the 1920s historical findings by Paton, one of the founding fathers of the ACC theory who argued for the necessity of taking people into account. Roslender (2009) however affirmed that efforts to account for people were promoted by the originators of the HRA discipline, which was the basis for this interrogation. Accordingly, it was possible to conclude that the AFP concept was firmly linked to HCA, which the author referred to as Human Asset accounting. A key question arose: are people equal to $\mathrm{HC}$ or HR? This review has distinguished between P, HR, and HC in Figure 2.2, and focused on the financial ACC for HC. Furthermore, HRA works experienced impediments in their earlier days because pundits feared the discipline aimed at treating people as financial objects. However, $\mathrm{P}$ is the EL in Figure 2.2, and whose value is innumerable in financial terms.

\subsubsection{Essential Elements}

The components of the HRA structure in Figure 2.1 have been applied interchangeably in the HCA discourse. However, each has been uniquely defined in this enunciation, as each has a constituent of HC measurement. Furthermore, outstanding distinctions between and among them, and especially how they relate with HCA were explored in this scrutiny for posterity, to promote HCA adoption in organizations. Researchers and students of HCA can draw from each appropriately to augment their views in support of HCA implementation, which promotes firms' market value.

\subsubsection{Models in HRA}

The HRA structure has originated the HRA Models. Models in HRA promote HC reporting in organizations as shown in Figure 2.1. These have been analyzed as (i) Measurement/quantification of $\mathrm{HC}$ intangibles as material investments in the financial statements of organizations; (ii) Field studies on HCA implementation in organizations; (iii) Analysis of tools employed in HC accounting/quantification; (iv) HRA as a strategic decision tool in organizations; (v) Debates in the HRA discourse; and (vi) Tailbacks in HRA growth (Flamholtz, Narasimhan, Bullen, 2004). However, the ecosystem was devoid of the International Accounting Standards Board's (IASB's) International Financial Reporting Standards (IFRSs) backing. IFRSs must be the implementers of the ACC practice in over 94\% of the world's nations which control approximately $98 \%$ of the global Gross Domestic Product (GDP). Whether or not the models would influence the IASB's work on IFRSs formulation towards pragmatic HCA implementation remained a fundamental research 
question.

\subsubsection{HC Communication Systems}

Although the statement of financial position (balance sheet) has been promoted as the principal platform for reporting $\mathrm{HC}$ intangibles, other communication systems such as (i) Management financial reports; (ii) organizations' official websites; (iii) Mainstream media platforms; as well as (iv) Social media outlets have become increasingly important in the contemporary accounting environment. Exploring these, and their consequent influence on firm prosperity remained a pertinent research question.

\subsubsection{Disclaimer}

I have investigated the measurement/quantification of $\mathrm{HC}$, to be reported as material investments in the Statement of financial position (balance sheet) of firms in my earlier survey works.

\section{References}

Abeysekera, I. (2008). Intellectual Capital Disclosure Trends: Singapore and Sri Lanka. Journal of Intellectual Capital, 9(4), 723-737. https://doi.org/10.1108/14691930810913249

Abhayawansa, S., \& Guthrie, J. (2016). Drivers and Semantic Properties of Intellectual Capital Information in Sell-Side Analysts' Reports. Journal of Accounting and Organizational Change, 12(4), 434-471. https://doi.org/10.1108/JAOC-05-2014-0027

Akintoye, I.R. (2012). The Relevance of Human Resource Accounting to Effective Financial Reporting. International Journal of Business Management \& Economic Research, 3(4), 566-572.

American Accounting Association (1973). Statement of Basic Accounting Theory: Evanston, IL AAA, Revised Edition.

American Institute of Certified Public Accountants (AICPA). (1970). Basic Concepts and Accounting Principles Underlying Financial Statements of Business Enterprises. Accounting Principles Board (APB); Statement No.4. NY.

Argyres, N.S., \& Liebeskind, J.P. (1999). Contractual Commitments, Bargaining Power, and Governance Inseparability: Incorporating History into Transaction Cost Theory. Academy of Management, 24(1), 49-63. https://doi.org/10.5465/amr.1999.1580440

Barney, J. (1991). Firm Resource and Sustained Competitive Advantage. Journal of Management, 17(1), 99-120. https://doi.org/10.1177/014920639101700108

Batra, G.S. (1996). Human Resource Auditing as a tool of Human Resource Valuation: Interface and Emerging Practices. Managerial Auditing Journal, 11(8), 23-30. https://doi.org/10.1108/02686909610131657

Becker, G.S. (1993). Human Capita: A Theoretical and Empirical Analysis with Special Reference to Education ( $3^{\text {rd }}$ ed.). University of Chicago Press, Chicago. 
https://doi.org/10.7208/chicago/9780226041223.001.0001

Bloomfield, R., Libby, R., \& Nelson, M. (2002). Experimental Research in Financial Accounting. Accounting Organization and Society, 27(8), 775-811. https://doi.org/10.1016/S0361-3682(01)00011-3

Butt, S.A. (2013). How to Bring Human Resource Asset into Balance Sheet. Pensee Multidisciplinary Journal, 75(2), 1-12.

Casio, W.F., \& Boudreau, J. (2011). Investing in People ( $2^{\text {nd }}$ ed.): Financial Impact of Human Resource Initiatives. Pearson Education Inc, New Jersey.

Chambers, R.J. (1993). Positive Accounting Theory and the PA Cult. Abacus, 29(1), 1-26. https://doi.org/10.1111/j.1467-6281.1993.tb00419.x

Chaudhry, N.I., \& Roomi, M.A. (2010). Accounting for the Development of Human Capital in Manufacturing Organizations: A Study of the Pakistani Textile Sector. Journal of Human Resource Costing and Accounting, 14(3), 178-195. https://doi.org/10.1108/14013381011095463

Chen, H.M., \& Lin, K.J. (2004). The Role of Human Capital Cost in Accounting. Journal of Intellectual Capital, 5(1), 116-130. https://doi.org/10.2307/3069366

Chouhan, V., \& Naghshbandi, N. (2015). Measuring Employees Value: A Critical Study on Human Resources Accounting in India. International journal of Management, accounting and Economics, 2(4), 277-292.

Dominguez, A.A. (2011). The Impact of Human Resource Disclosure on Corporate Image. Journal of Human Resource Costing and Accounting, 15(4), 279-298. https://doi.org/10.1108/14013381111197225

Dumay, J., \& Guthrie, J. (2017). Involuntary Disclosure of Intellectual Capital: Is it Relevant? Journal of Intellectual Capital, 18(1), 29-44. https://doi.org/10.1108/JIC-110-2016-0102

Fields, T., Lys, T., \& Vincent, L. (2001). Empirical Research on Accounting Choice. Journal of Accounting and Economics, 31, 225-307. https://doi.org/10.1016/S0165-4101(01)00028-3

Flamholtz, E.G. (1999). Human Resource Accounting: Advances, Concepts, Methods and Applications. Boston MA: Kluwer academic publishers. https://doi.org/10.1007/978-1-4615-6399-0

Flamholtz, E.G. (2005). Conceptualizing and Measuring the Economic Value of Human Capital of the Third Kind. Journal of Human Resource Costing and Accounting, 9(2), 78-93. https://doi.org/10.1108/14013380510645360

Flamholtz, E.G., Narasimhan, R.K., \& Bullen, M.L. (2004). Human Resource Accounting Today: Contributions, Controversies and Conclusions. Journal of Human Resource Costing and Accounting, 8(2), 23-37. https://doi.org/10.1108/eb029084

Foster, J.F. (2001). The Relationship between the Theory of Value and Economic Analysis. 
Journal

of

Economic

$15(4)$

899-905.

https://doi.org/10.1080/00213624.1981.11503913

Gamerschlag, R. (2013). Value Relevance of Human Capital Information. Journal of Intellectual Capital, 4(2), 325-345. https://doi.org/10.1108/14691931311323913

Hermanson, R.H. (1986). Accounting for Human Assets. Research Monograph No. 99, Business Publishing Division, College of Business Administration, Georgia State University, Atlanta Georgia.

Hooghiemstra, R. (2000). Corporate Communication and Impression Management: New Perspectives Why Companies Engage in Corporate Social Reporting. Journal of Business Ethics, 27(1/2), 55-68. https://doi.org/10.1023/A:1006400707757

Imke, F.J. (2001). Relationships in Accounting Theory. The Accounting Review, 318-322.

Ijiri, Y. (1975). Theory of Accounting Measurement: Studies in Accounting Research. American Accounting Association, Sarasota, Florida.

Jensen, H. (2001). Policy and Company Perspectives for IC Reporting. Journal of Human Resource Costing and Accounting, 6(1), 11-28. https://doi.org/10.1108/eb029069

Johanson, U. \& Mabon, H. (1998). The Personnel Economics Institute after Ten Years: What has Been Achieved and Where We Are Going? Journal of Human Resource Costing and Accounting, 3(2), 65-76. https://doi.org/10.1108/eb029049

Joskow, P.L. (1993). Asset Specificity and the Structure of Vertical Relationships: Empirical Evidence. Oxford University Press.

Kabir, H. (2005). Normative accounting Theories. SSRN Electronic Journal. https://doi.org/10.2139/ssrn.765984

Kaplan, R.S., \& Norton, D.P. (1992). The Balanced Scorecard: Measures that Drive Performance. Harvard Business Review, 70(1), 71-79.

Karthikeyan, S., Bhagat, M., \& Kannan, N.G. (2012). Making the HR Outsourcing Decision-Lessons from the resource-Based View of the Firm. International Journal of Business Insights \& Transformation, 5(1), 87-95.

Kaur, S., Raman, A.V., \& Singhania. (2014). Human Resource Accounting Disclosure Practices in Indian companies. Vision, 18(3), 217-235. https://doi.org/10.1177/0972262914540227

Kothari, S. P. (2001). Capital Markets Research in Accounting. Journal of Accounting and Economics, 31, 105-231. https://doi.org/10.1016/S0165-4101(01)00030-1

Lepak, D.P., \& Snell, S.A. (1999). The Human Resource Architecture: Toward a Theory of Human Capital Allocation and Development. Academy of Management Review, 24(1), 31-48. https://doi.org/10.5465/amr.1999.1580439

Lio, S. (2018). Kiss Firms Which Embrace Accounting for Human Capital Have Emerged in 
Kenya. Academy of Accounting and Financial Studies Journal, 22(1), 1-14.

Littleton, A.C. (1953). Structure of Accounting Theory. Monograph No. 5. American Accounting Association, Florida.

Massingham, P., Nguyen, T.N., \& Massingham, R. (2011). Using 360 Degree Peer Review to Validate Self-Reporting in Human Capital Measurement. Journal of Intellectual Capital, 12(1), 43-74.

Miller, P.B., \& Bahnson, P.R. (2010). Continuing the Normative Dialog: Illuminating the Asset/Liability Theory. American Accounting Association, 24(3), 419-440. https://doi.org/10.2308/acch.2010.24.3.419

Murthy, V., \& Guthrie, J. (2012). Management Control of Work-life Balance: A Narrative Study of an Australian Financial Institution. Journal of Human Resource Costing and Accounting, 16(4), 258-280. https://doi.org/10.1108/14013381211317248

Perara, M.H.B., \& Matthew, M.R. (1996). Accounting Theory and Development. Australia International Thomson Publishing Co.

Porter, M.E.(1985). Competitive Advantage Creating and Sustaining Superior Performance. Free Press, NY.

Porter, M.E., \& Stern, S. (2001). Innovation Location Matters. Sloan Management Review, 28-36.

Ramirez, C., \& Jeanjean, T. (2009). Back to the Origins of Positive Theories: A Contribution to an Analyses of Paradigm Changes in Accounting Research. Accounting in Europe, 6(1), 107-126. https://doi.org/10.1080/17449480902896510

Ray, G., Barney, J.B., \& Muhanna, W.A. (2004). Capabilities, Business Processes and Competitive Advantage: Choosing the Dependent Variable in Empirical Tests of the Resource-Based-View. Strategic Management Journal, 25, 23-37. https://doi.org/10.1002/smj.366

Riordan, M.H., \& Williams, O.E. (1985). Asset Specificity and Economic Organization. International Journal of Industrial Organization, 3, 365-378. https://doi.org/10.1016/0167-7187(85)90030-X

Roslender, R. (2009). So Tell me Again...Just Why Would you want to Account for People? Journal of Human Resource Costing and Accounting, 13(2), 311-329. https://doi.org/10.1108/14013380910968656

Sadan, S., \& Auerbach, L.B. (1974). A Stochastic Model for Human Resources Valuation. California Management Review, 16(4), 24-31. https://doi.org/10.2307/41164524

Samudhram, A., Shanmugam, B., \& Low, K.L (2008). Valuing Human resources. Journal of Intellectual Capital, 9(4), 655-667. https://doi.org/10.1108/14691930810913203

Schepker, D.J., Oh, W.Y., Martynov, A., \& Poppo, L. (2014). The Many Futures of Contracts 
Moving Beyond Structure and Safeguarding to Coordination and Adaptation. Journal of Management, 40, 193-225. https://doi.org/10.1177/0149206313491289

Sinha, S.K. (2008). Positive Accounting Theory: A Critique. The ICFAI University Journal of Accounting Research, 7(4), 7-16.

Steen, A., Welch, D., \& McCormack, D. (2011). Conflicting Conceptualization of Human Resource Accounting. Journal of Human Resource Costing \& Accounting, 15(4), 299-312. https://doi.org/10.1108/14013381111197234

Sveiby, K.E. (1997). The New Organizational Wealth: Managing and Measuring Knowledge-Based Assets. Berrett-Korhler. San Francisco, CA.

Theeke, H.A. (2005). A Human Resource Accounting Transmission: Shifting from Failure to Future. Journal of Human Resource Costing \& accounting, 9(1), 40-59. https://doi.org/10.1108/14013380510636694

Tong, A., Sainsbury, P., \& Craig, J. (2007). Consolidated Criteria for Reporting Qualitative Research (COREQ): A 32-Item Checklist for Interviews and Focus Groups. International Journal for Quality in Health Care, 19(6), 349-357. https://doi.org/10.1093/intqhe/mzm042

Watts, R. L., \& Zimmermann, J. L. (1986). Positive Accounting Theory. Englewood Cliffs. Prentice-Hall.

Wolk, H.I., Dodd, J.L., \& Rozycki, J.J. (2008). Accounting Theory: Conceptual Issues in a Political and Economic Environment ( $7^{\text {th }}$ ed.) Sage Publications Inc. California. 